\title{
Agroforestry parkland profiles in three climatic zones of Burkina Faso
}

\author{
Tiga NEYA ${ }^{1 *}$, Oble NEYA ${ }^{2}$ and A. Akwasi ABUNYEWA ${ }^{3}$ \\ ${ }^{1}$ Kwame Nkrumah University of Sciences and Technology of Ghana Kumasi, \\ Department of Civil Engineering, Ghana. \\ ${ }^{2}$ West African Science of Climate Change and Adapted Land Use, \\ Competence Centre Ouagadougou, Burkina Faso. \\ ${ }^{3}$ Kwame Nkrumah University of Sciences and Technology of Ghana Kumasi, \\ Department of Agroforestry, Ghana. \\ "Corresponding author; E-mail: neyatiga@gmail.com ; Tel :(00226) 79072888
}

\section{ACKNOWLEDGEMENTS}

Authors thank WASCAL for financial support to this research.

\begin{abstract}
Agroforestry plays an important role in food security and farmer's resilience to climate change and variability in West Africa. However agroforestry parkland profile in the climatic zone in Burkina Faso are not well known. Therefore, agroforestry parkland profiles in three climatic zones of Burkina Faso were studied. Thirty (30) farmlands in each climatic zone representing about 35 ha were randomly selected on which systematic woody species inventory and dendrometry data collection was undertaken. Diameter classes' distribution and agroforestry parkland typologies using Importance Value Index analysis were also done. The results showed 42, 31 and 34 woody species respectively in Sudanian, Sudan-Sahel and Sahel strict zones with corresponding density of 37, 30 and 35 trees/ha. Agroforestry parklands in Sudan-Sahel zone appeared to be unstable compared with the two others climatic zones. Mono-woody species parkland of Vitellaria paradoxa was observed in the Sudanian zone while multi-woody species parklands were observed in the Sudan-Sahel and Sahel strict zones. Both the density of trees/ha and the number of species constituting the agroforestry parklands have a direct impact of carbon sequestration potential. Taking in account agroforestry parklands profile is therefore determinant in evaluating smallholders' farmers in potential benefit from carbon market in each climatic zone.
\end{abstract}

(C) 2018 International Formulae Group. All rights reserved.

Keywords: Parkland typology, woody species, density, smallholders.

\section{INTRODUCTION}

In sub-Saharan Africa, where agriculture is rain feed and characterised by smallholder farming, farmers developed several strategies to cope with low and variable productivity (Mertz et al., 2009; Nhemachena, 2009; Pouliotte et al., 2009).
Among these strategies agroforestry is one of the most known and spread, and is also being used as a strategy to handle the effects of climate variability and change (Miguel et al., 2011; Nair et al., 2009).

In Burkina Faso, rain becomes more and more scarce endangering food production 
and exposing more and more smallholders to food insecurity these last decades (Pare et al., 2008; Ouedraogo et al., 2009; Vliet et al., 2013; Neya et al., 2017). Likewise, in other sub-Saharan countries, agroforestry is practiced and cited as a mean or strategy to cope with productivity uncertainty as well as with impact of climate change and climate variability in the country (Yameogo et al., 2005). Based on that and its contribution to both local and national economies; agroforestry parklands are suggested and recommended to smallholder farmers as mean to improve their resilience to food insecurity and to mitigate climate change (; Miguel et al., 2011; Tiébré et al., 2016; Angoni et al., 2018 ). It is known that goods and services provided by agroforestry parklands are highly dependent on the types and the density of woody species present in the farm (Nair et al., 2009; Miguel et al., 2011; Teklehaimanot et al., 2012). Also, one of the key factors that can influence agroforestry parklands profile is climate (Pouliotte et al., 2009; Miguel et al., 2011). So far, few studies taking in account climatic zones were done on agroforestry parklands profiles particularly in Burkina Faso (Yameogo et al 2005; Bationo et al., 2012,). Therefore, the current study aiming at characterizing the profiles of the agroforestry parklands in three climate zones is proposed to appreciate their stabilities. This characterization will be important to understand farmers' strategies that shape these agroforestry parklands and to get better insight in what could be the contribution of agroforestry parklands to carbon sequestration. Indeed, reliable data on agroforestry parklands profiles and their capabilities to perform as carbon sinks, become important to support decision- and policy-making particularly in the framework of country's Intended Nationaly Determined Contribution (INDCs) implementation. The study specific objectives are to (i) identify tree species forming agroforestry parklands in three climatic zones, (ii) investigate the structural characteristics of tree species in those parklands and (iii) characterize the parklands profiles based on dominant species.
The overall hypothesis is that woody species, their density and agroforestry parkland profiles are related to climatic conditions.

\section{MATERIALS AND METHODS}

\section{Study area description}

The study was carried out in three climatic zones (Figure1) of Burkina Faso namely the Sahel strict, the Sudan-Sahel and the Sudanian zones as defined by the second national forestry inventory (IFN2) in 2012 (Figure1). The Sahel strict climatic zone is characterized by shrubby steppes developing towards the south into wooded steppes. The soil is characterized by ferruginous leached deep soils, brown soils and hydromorphic soils (Bunasols 1992). The annual rainfall in this zone is less than $600 \mathrm{~mm}$. The annual rainfall in Sudan-Sahel ranges between 600 to $900 \mathrm{~mm}$. Its vegetation is characterized by agricultural landscape dominated by protected species such as Vitellaria paradoxa, Parkia biglobosa, Tamarindus indica (), Adansonia digitata. Breastplates and iron shells are the main soil types in this climatic zone. Sudanian zone with annual rainfall greater than $900 \mathrm{~mm}$ is the most humid climatic zone of the country. It is characterized by woody savannas and forest (Guinko, 1984) with acidic metamorphic rocks and coarse texture in the topsoil.

In each climatic zone, one community (municipality) was considered for this study. So, there were Ouahigouya, located in the north region for the Sahel strict zone, Sapouy, in the Centre-west, for the Sudan-Sahel zone and Bouroum-Bouroum located in the Southwest for the Sudanian zone. The three communities were chosen because of farmers experience and ability to work with partners gained through previous works with the National Forestry Investment programme (FIF) and the Ecosystem Based Adaptation project (EBA). Agroforestry parkland (AFP) is defined as a land-use that associates at least ten (10) ligneous tree (ie, trees, shrubs, etc.) with one or more annual crops (food or cash crop), in an agricultural area superior to 2500 $\mathrm{m}^{2}$ (Wala et al., 2005). In this study, AFP profile is defined as the woody species 
richness, parkland structure (woody species density and their diameter at breast distribution) and the type of landscape structure (multispecies or mono species). In each of the three communities, households were selected as described below for data collection.

\section{Households selection}

In each community representing a climatic zone, five villages were randomly selected by using the different name of all implemented villages of projects EBA et FIP) and in each village six household farms were also randomly selected giving a total of 30 households used to characterise AFP profiles in each climatic zone. These 30 households were selected among farmers who have participated in similar activities with the Forestry Investment Programme (FIP) or the Ecosystem Based Adaptation Project. In the selected farms, woody species diversity and their structure were used to define AFPs profile in each zone. The study was focused on smallholder farmers, meaning farmers owning farms between 2500 to $30000 \mathrm{~m}^{2}$, the maximum size defined for smallholder farm in Burkina Faso (MECV 2009). These sizes are the minimum plot size to carry out an agroforestry study (Wala et al., 2005).

\section{Woody species inventory}

To assess trees species diversity, each AFP was geolocalized and tracked using a Global Positioning System (GPS), to record its total area where systematic inventory of trees species was conducted. This included scientific name identification of each woody species within each farm following measurement of their diameter at breast height (DBH) using a tape. In case of doubt about scientific identification of a species, the name in local languages was recorded and specimen of unknown species for determination using determination keys (flora of Senegal, Benin) or by comparing the specimens of those of a herbarium for better identification later. However Shannon $(\mathrm{H})$ Indices has been used to appreciate the richness of woody species in the three communities (Eq1)
$H=\sum_{i=1}^{n} p_{i} \ln p_{i}$

$\mathrm{n}=$ total number of species in the community

$\mathrm{pi}=$ relative abundance of $\mathrm{i}$ species in the farm.

ln: Neperien logarithm

$\mathrm{H}$ : Shannon indices.

\section{Agroforestry parkland structure}

The structure of AFP in each climatic zone was characterised through the computation of relative density of trees in the farm and establishment of stem diameter structures using the DBH distribution.

\section{Woody species density}

The spatial structure referred to the density of individuals' tree in a known area and the density was obtained using the total number of woody species obtained in the give area over the area in hectare. Later on, the values per plot/farm were upscaled to villages and community levels.

\section{Size-class distribution}

Distribution of tree diameters at breast height $(\mathrm{DBH})$ or diameter at $1.3 \mathrm{~m}$ was established based on the following ten (10) classes in cm: [2-10], ]10-20], ]20-30], ]3040], ]50-60], ]60-70], ]70-80], ]80-90], ]90100] and ]100-110] and the total individual number of woody species per class was recorded using Minitab 17 software This distribution of tree diameters was used as an indicator of the stability or sustainability of the parklands.

\section{Agroforestry parklands profile}

To determine AFP profiles, the Importance Value Index (IVI) was used. IVI referred to the abundance of each species which may be considered as the representativeness of each species in the farms (Eq 5). Before calculating the IVI, Relative density (RDi), Relative frequency ( $\mathrm{RFi}$ ) and Relative dominance (RDomi) of each woody species were first calculated (Equations 2, 3 and 4). The Data obtained were used to determine and rank the contribution (C) of 
each woody species to the agroforestry parkland formation (Eq 6). Woody species whose sum of contributions is equal or greater than $70 \%$ were used to label the AF parkland of the community under consideration.

$$
R D i=\frac{\text { Density of species } A i}{\text { Total density for all species }} * 100
$$

Where Ai : given woody specie

$$
R F i=\frac{\text { Frequency valuefor species } A i}{\text { Total frequency values for all species }} * 100
$$

$$
\text { RDomi }=\frac{\text { Dominance for species } A i}{\text { Total dominance for all species }} * 100
$$

$$
\begin{aligned}
& I V I(A i)=R D i+R F i+R D o m i \\
& \mathrm{C}=1_{00 \mathrm{IVI}_{(\mathrm{Ai})} / \sum\left(\mathrm{IVI}_{(\mathrm{Ai})}\right)}
\end{aligned}
$$

where $\mathrm{C}_{\mathrm{Ai}}$ : woody specie (Ai) contribution to parkland landscape formation.

\section{Statistical analysis}

One-way ANOVA and Fisher, Turkey and Dunnett statistical tests were applied, to compare the above detailed parameters in the three climatic zones. Minitab 17, Sigma plot 13.0 and excel 2010 software were used to plot the figures.

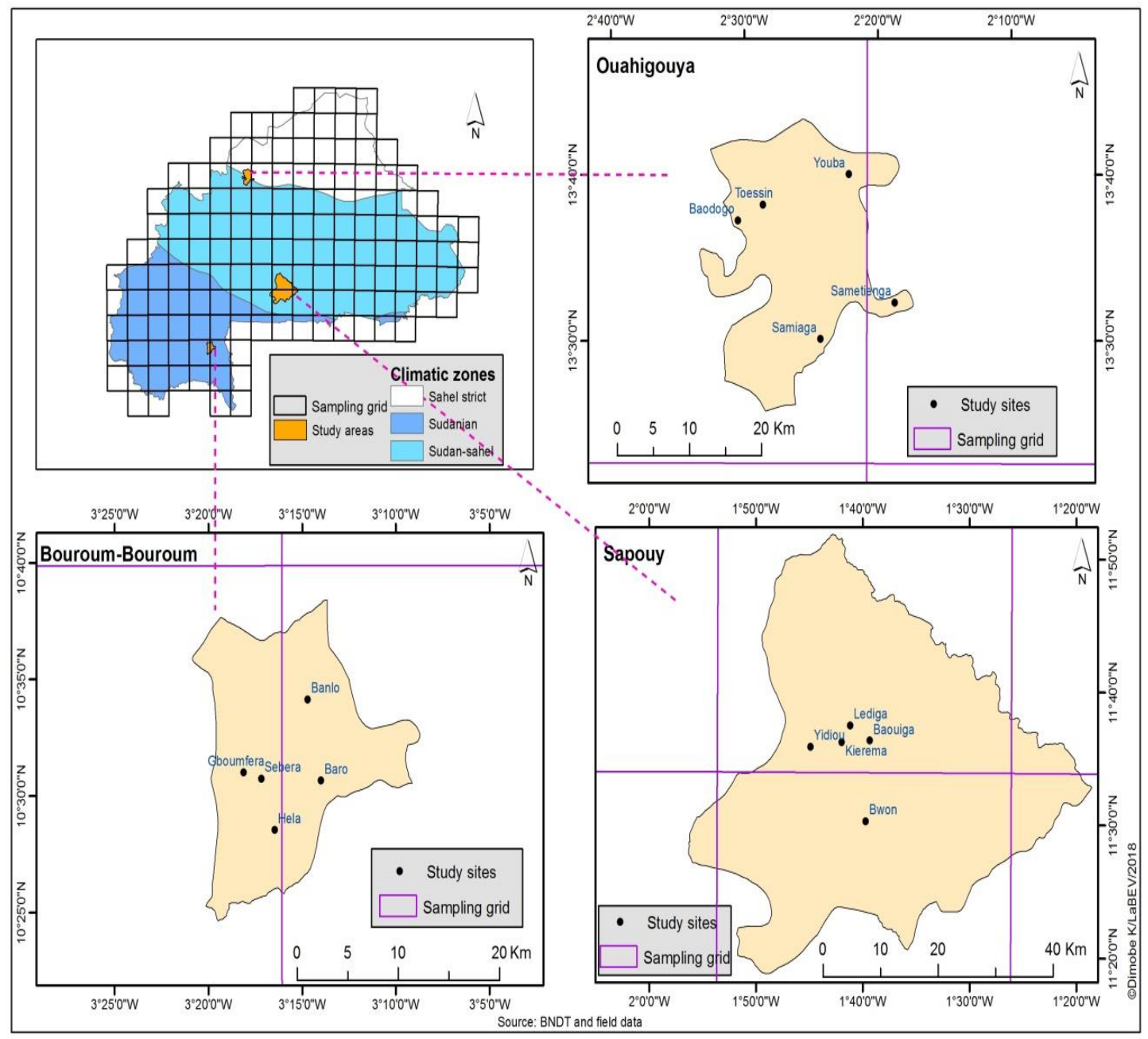

Figure 1: Climatic zones of Burkina Faso and study communities: Ouahigouya for Sahel strict, Sapouy for Sudan-Sahel zone and Bouroum-Bouroum for Sudanian zone. 


\section{RESULTS}

\section{Dominant woody species}

The 30 selected farms in each climatic zone cover a total area about 35 ha. Woody species richness in these farms was 42,31 and 34 species (Table 1) respectively for the Sudanian zone represented by Bouroumbouroum, the Sudan-Sahel zone represented by Sapouy and the Sahel strict represented by Ouahigouya community (Figure 2). Twelve woody species were common to the three zones and include Vitellaria paradoxa, Tamarindus indica, Entada africana, Parkia biglobosa, Moringa oleifera, Lannea microcarpa, Diospyros mespiliformis, Bombax costatum, Azadirachta indica, Anogeissus leiocarpa, Afzelia Africana, and Acacia macrostachya. Among these 12 species found in the three zones, only Moringa oleifera and Azadirachta indica are not local species and are considered as planted or introduced species. However the richness analysis with Shannon (H) Index shown Ouahigouya community more rich in woody species compared to both Bouroum-Bouroum and Sapouy communities (Table 2).

\section{Woody species density}

The lowest density of woody species was $30 \pm 7$ trees/ha observed in Sapouy community in the Sudan-Sahel zone, while the highest was $37 \pm 7$ trees/ha observed in Bouroum-Bouroum in the Sudanian zone (Figure 2). The mean comparison analysis with Fisher test at $(\mathrm{P}=0.406)$ revealed that there was no significance difference between tree density in the three climatic zones.

\section{Size-class distribution}

In all the research sites, few individual trees had DBH greater than $40 \mathrm{~cm}$. In Bouroum-Bourom (Sudanian zone) and Ouahigouya (Sahel strict zone), tree diameters had a regular distribution with the density per class decreasing when the diameter class is increasing (Figure 3A and 3B). Regarding Sapouy, diameter classes between 2 and 10 $\mathrm{cm}$ were almost missing. This created an irregular distribution of diameter classes in this zone (figure 3C).

\section{Parkland profiles}

Using species Importance Value Index (IVI) to characterize AFP profiles allowed identifying a total of eight (8) tree species that are profiling agroforestry parklands in the three climatic zones. In Ouahigouya (Sahel strict zone), six (06) species constituted the agroforestry parklands. These include Adansonia digitata, Azadirachta indica, Balanites aegyptiaca, Faidherbia albida, Lannea microcarpa and Sclerocarya birrea (Figure 4A). In Sapouy (Sudan-Sahel zone), three (03) species constituted agroforestry parklands were formed out of Vitellaria paradoxa, Parkia biglobosa and Bombax costatum (Figure 4B) while in BouroumBouroum (Sudanian zone), one species namely Vitellaria paradoxa provided more than $70 \%$ of the total IVI, indicating that agroforestry parklands were mainly formed by this species (Figure 4C).

Table1: Agro-woody species-diversity per study's zone.

\begin{tabular}{lccc}
\hline Woody Species & Bouroum-Bouroum & Ouahigouya & Sapouy \\
\hline Acacia gourmagneisis & - & $\mathrm{x}$ & - \\
Acacia macrostachya $^{*}$ & $\mathrm{x}$ & $\mathrm{x}$ & $\mathrm{x}$ \\
Acacia nilotica & - & $\mathrm{x}$ & - \\
Acacia seyal & $\mathrm{x}$ & $\mathrm{x}$ & - \\
Acacia tortilis & - & $\mathrm{x}$ & - \\
Adansonia digitata & $\mathrm{x}$ & $\mathrm{x}$ & - \\
Afzelia Africana & $\mathrm{x}$ & $\mathrm{x}$ & $\mathrm{x}$ \\
\hline
\end{tabular}




\begin{tabular}{|c|c|c|c|}
\hline Anacardium occidentale & $\mathrm{x}$ & - & - \\
\hline Anogeisus leiocarpus* & $\mathrm{x}$ & $\mathrm{x}$ & $\mathrm{x}$ \\
\hline Azadirachta indica* & $\mathrm{x}$ & $\mathrm{x}$ & $\mathrm{x}$ \\
\hline Balanites aegyptiaca & - & $\mathrm{x}$ & $\mathrm{x}$ \\
\hline Bauhinia rufescens & - & $\mathrm{x}$ & - \\
\hline Bligia sapida & $\mathrm{x}$ & - & - \\
\hline Bombax costatum* & $\mathrm{x}$ & $\mathrm{x}$ & $\mathrm{x}$ \\
\hline Burkea Africana & $\mathrm{x}$ & & $\mathrm{x}$ \\
\hline Casia siamea & $\mathrm{x}$ & - & - \\
\hline Cacia siberiana & - & $\mathrm{x}$ & $\mathrm{x}$ \\
\hline Combretum fragrans & $\mathrm{x}$ & - & $\mathrm{x}$ \\
\hline Combretum Micrantum & $\mathrm{x}$ & - & - \\
\hline Combretum sp & $\mathrm{x}$ & - & - \\
\hline Cordia myxa & $\mathrm{x}$ & - & - \\
\hline Combretum glutinosum & - & $\mathrm{x}$ & - \\
\hline Daniela oliveri & $\mathrm{x}$ & - & $\mathrm{x}$ \\
\hline Detarium microcarpum & $\mathrm{x}$ & - & $\mathrm{x}$ \\
\hline Diospyros mespiliformis* & $\mathrm{x}$ & $\mathrm{x}$ & $\mathrm{x}$ \\
\hline Entada africana $*$ & $\mathrm{x}$ & $\mathrm{x}$ & $\mathrm{x}$ \\
\hline Ecaliptus camadulensis & - & - & $\mathrm{x}$ \\
\hline Faidherbia albida & $\mathrm{x}$ & $\mathrm{x}$ & - \\
\hline Ficus dekdekena & $\mathrm{x}$ & - & $\mathrm{x}$ \\
\hline Ficus sycomorus & $\mathrm{x}$ & $\mathrm{x}$ & \\
\hline Gardenia erubescens & - & $\mathrm{x}$ & $\mathrm{x}$ \\
\hline Gmelina arborea & $\mathrm{x}$ & - & $\mathrm{x}$ \\
\hline Guiera senegalensis & - & $\mathrm{x}$ & - \\
\hline Grewia bicolor & - & $\mathrm{x}$ & - \\
\hline Jatropha curcas & $\mathrm{x}$ & - & - \\
\hline Khaya senegalensis & $\mathrm{x}$ & - & $\mathrm{x}$ \\
\hline Lannea acida & $\mathrm{x}$ & - & $\mathrm{x}$ \\
\hline Lannea microcarpa* & $\mathrm{x}$ & $\mathrm{x}$ & $\mathrm{x}$ \\
\hline Lannea velutina & $\mathrm{x}$ & - & $\mathrm{x}$ \\
\hline Mangifera indica & $\mathrm{x}$ & $\mathrm{x}$ & - \\
\hline Mitragyna inermis & $\mathrm{x}$ & - & - \\
\hline Moringa oleifera* & $\mathrm{x}$ & $\mathrm{x}$ & $\mathrm{x}$ \\
\hline Noclea latifolia & $\mathrm{x}$ & - & - \\
\hline Parkia biglobosa* & $\mathrm{x}$ & $\mathrm{x}$ & $\mathrm{x}$ \\
\hline Piliostigma reticulatum & - & $\mathrm{x}$ & - \\
\hline Prosopus africana & $\mathrm{x}$ & - & $\mathrm{x}$ \\
\hline Psidium guajava. & - & $\mathrm{x}$ & - \\
\hline Pterocarpus erinanceus & $\mathrm{x}$ & - & $\mathrm{x}$ \\
\hline Pterocarpus lucens & - & $\mathrm{x}$ & - \\
\hline Sclerocarya birrea & - & $\mathrm{x}$ & $\mathrm{x}$ \\
\hline
\end{tabular}




\begin{tabular}{lccc}
\hline Stereospermum kunthianum & $\mathrm{x}$ & $\mathrm{x}$ & - \\
Sterculia setigera & $\mathrm{x}$ & - & $\mathrm{x}$ \\
Strychnos spinosa & $\mathrm{x}$ & - & $\mathrm{x}$ \\
Tamarindus indica* $^{*}$ & $\mathrm{x}$ & $\mathrm{x}$ & $\mathrm{x}$ \\
Terminalia glaucescens $_{\text {Terminalia macroptera }}$ & - & - & $\mathrm{x}$ \\
Terminalia mentali & - & - & $\mathrm{x}$ \\
Vitellaria paradoxa* & - & $\mathrm{x}$ & - \\
Vitex doniana & $\mathrm{x}$ & $\mathrm{x}$ & $\mathrm{x}$ \\
Ziziphus mauritiana & $\mathrm{x}$ & - & - \\
\hline Total & - & $\mathrm{x}$ & - \\
\hline
\end{tabular}

*: the woody species has been fine in the three sites of study. X: woody species has been found in the site-: woody species has not been found in the site.

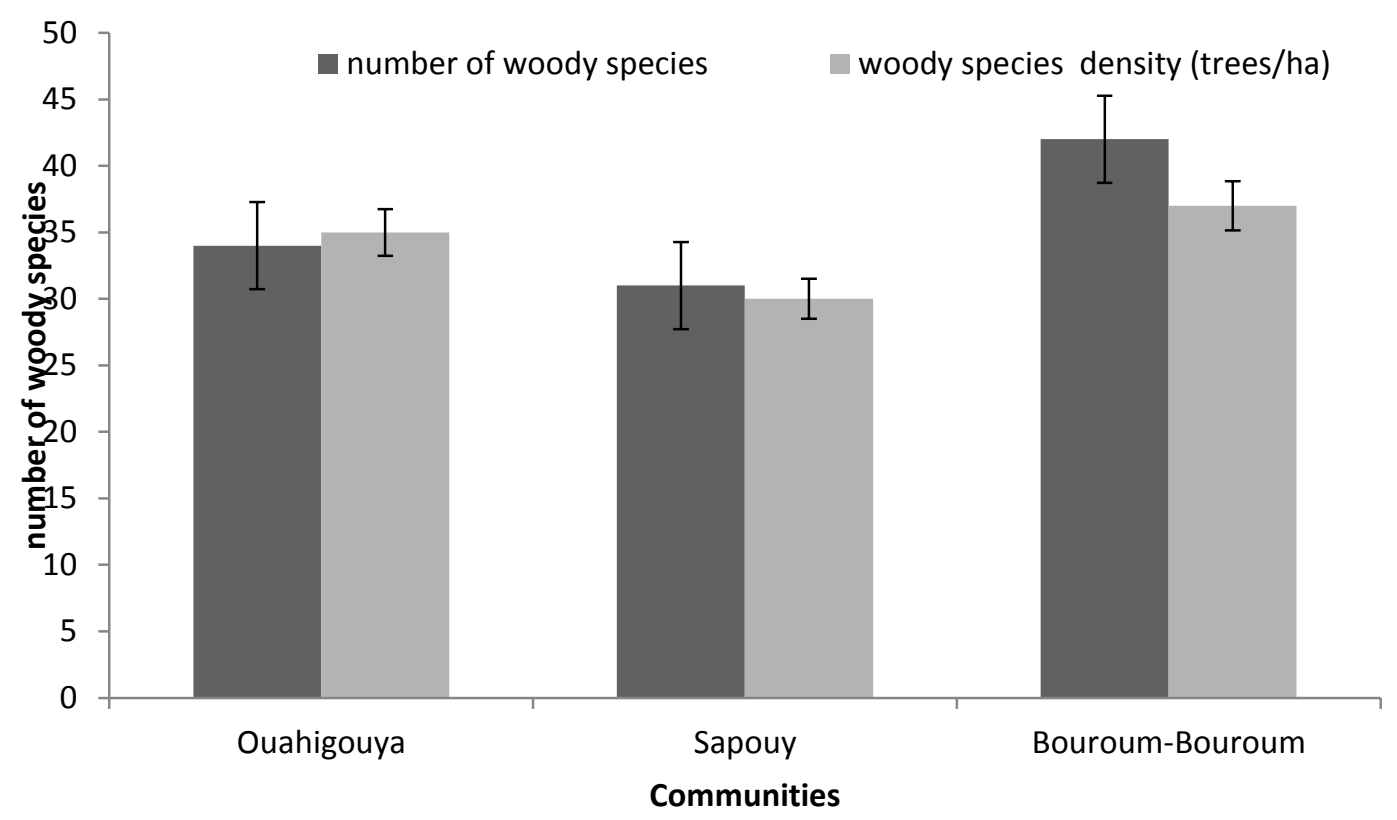

Figure 2: Number of woody species (dark bars) and mean trees density and (grey bars) in the three studied communities (Ouahigouya, Sapouy and Bouroum-Bouroum). Each bar with standard deviation presented average obtained from 30 farms, $\mathrm{P}<0.001$.

Table 2: Woody species richness per community.

\begin{tabular}{lc}
\hline Communities & Shannon (H) Indices \\
\hline Bouroum-Bouroum & 1.71 \\
Sapouy & 1.36 \\
Ouahigouya & 2.7 \\
\hline
\end{tabular}




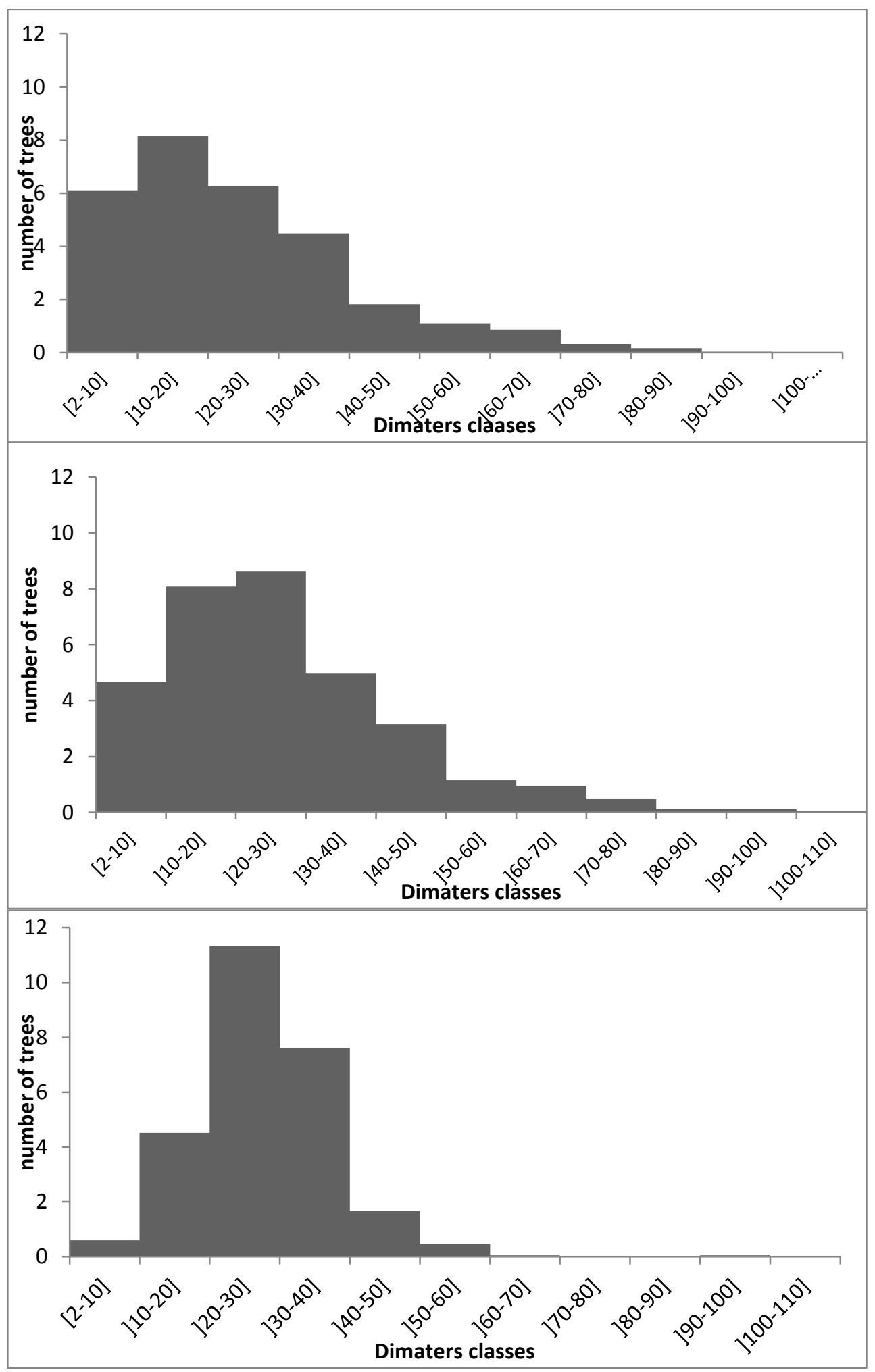

Figure 3: Trees diameter classes' distribution in the three studied communities: BouroumBouroum (A) Ouahigouya (B) and Sapouy (C). Data were collected in each community from 30 farms representing an area of about 35 ha. 


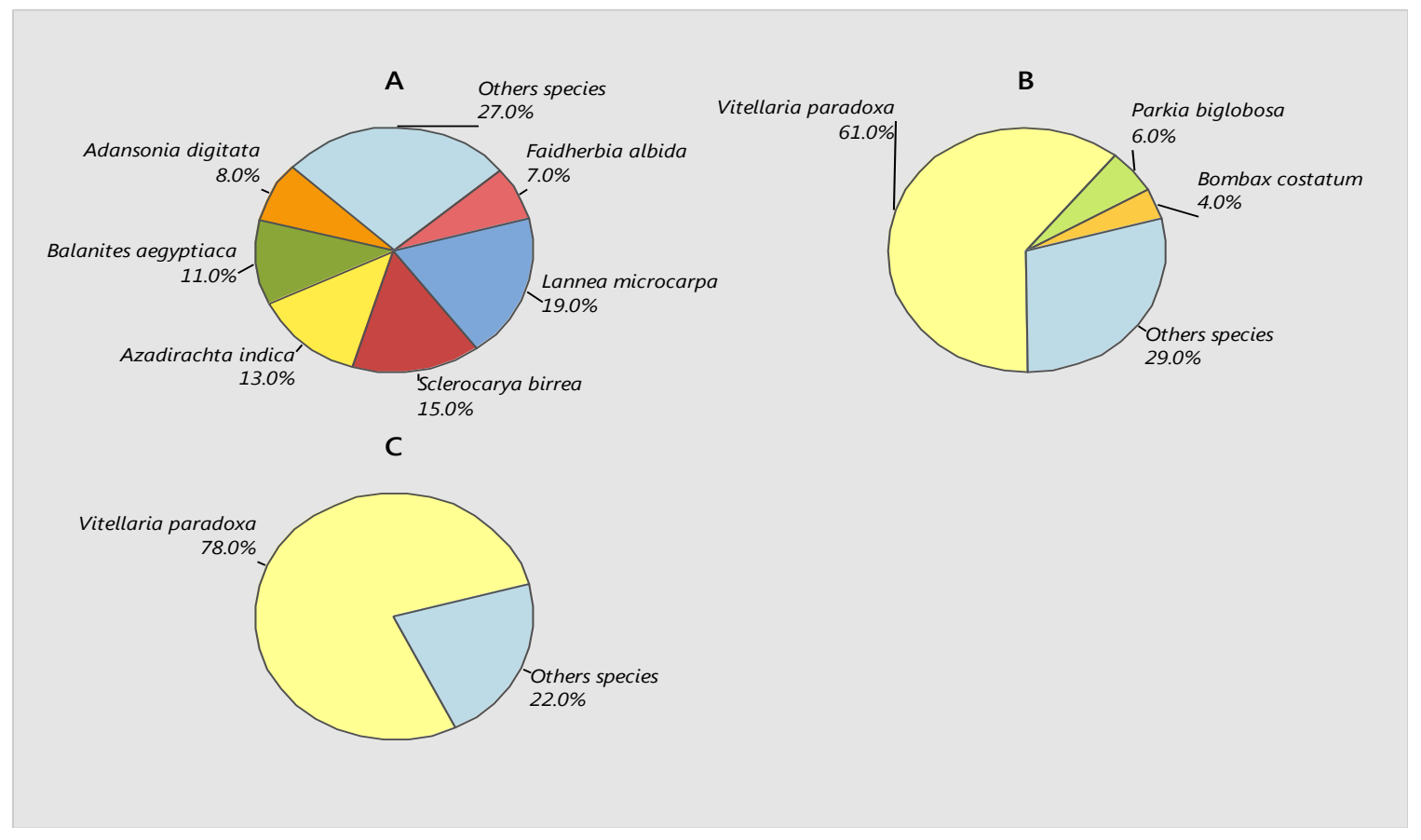

Figure 4: Woody species contribution to parkland profiles in the three studied communities: Ouahigouya (A), Sapouy (B) and Bouroum-Bouroum (C). Data were collected in each community from 30 farms representing an area of about 35 ha.

\section{DISCUSSION}

The total number of species found in AFP was higher in the Sudanian zone (Bouroum-Bouroum) compared with the two other climatic zones namely the Soudan-Sahel zone (Sapouy) and the Sahel strict zone (Ouahigouya). But richness analysis revealed the Sahel strict zone (Ouahigouya) more rich in woody species compared to both BouroumBouroum and Sapouy (Table 2). However, statistical analysis showed that these differences were not significant. In other words, no effect of climate variability on total number of species was demonstrated. Nevertheless, the fact that the total number of species found in the Sudan-Sahel zone was less than the one in Sahel-strict zone was somehow surprising. There is good reason to suspect that the development of agribusinesses (cotton production, sesame maize) in the area of Sapouy, which intensifies agricultural mechanization, has led the reduction of the number of trees in farms, which indirectly reduce the number of species and the presence of young individual trees in AFPs. On the other hand, in the surrounding of Ouahigouya, where rainfall is more and more scarce, the high number of woody species and high richness found in AFP, could be an adaptation strategy developed by farmers to diversify their productions and better cope with crops production chocs.

Among the 12 common species to all the three study zones, only Moringa oleifera and Azadirachta indica are exotic species and can be considered as planted or introduced purposely in the farms. Likewise, the total number of species, trees density did not show a significant difference between the three climatic zones at $\mathrm{P}<0.406) \quad$ Moreover, the fact that the density observed in Sapouy $(30.38 \pm 7.09$ tree/ha) was less compared to the one obtained in Ouahigouya (35 \pm 7.09trees/ha) further shows that woody species density in AFPs is not necessarily function of rainfall (Figure 2). These results corroborate the findings of Bayala et al. (2014) who showed that trees density in farm 
in Burkina Faso vary from one site to another and is relatively function to farmers decision and following the environmental adversity.

Regarding the structure of the different AFP, it was observed that diameter classes [2$20 \mathrm{~cm}$ ] and] $50-110 \mathrm{~cm}$ ] were missing in Sapouy while all the diameter classes were found in Ouahigouya and Bouroum-Bouroum (Figure 3). The lack of these two classes can be interpreted as serious threat to the sustainability of AFPs in this climatic zone because the absence of individuals in the low diameter class is an indication of low regeneration while the absence of individual with big DBH would mean the lack of old individuals to secure seeds production and perpetuate the population. In other words agroforestry parklands in Sapouy could be qualified as unstable compared to those in Bourou-Bouroum and Ouahigouya. This instability of agroforestry parklands in Sapouy zone can be explained by agricultural mechanization in this area. Similar instable structure was reported by Thiombiano et al. (2013) for APFs constituted of Vitellaria paradoxa, Parkia biglobosa and Lannea microcarpa, in the Southern Center of Burkina Faso (community of Nobéré), located in the same climatic zone as Sapouy. As for agroforestry parklands in Ouahigouya, where individuals were recorder in all diameters classes despite the relative low rainfall in this climatic zone, this can be explained by the promotion of assisted natural regeneration activities in this regions by some project such as NEER Tamba, Ecosystem Based Adaption, project. National Territorial Management Program; Degraded Land Recovery project in the Sahel and NGO'S such as 'Six S' (MEF 2010). Several studies argue that unstable structure of agroforestry parklands is due to bad regeneration of species and water scarcity, while a stable structure depends mainly on the good regeneration of the species (Agali, 2009; Thiombiano et al., 2013). The decrease of tree density with increase in diameter can be explained by the management practices of farmers.

It was observed that from North to the South, agroforestry parklands landscapes transited from multi-woody species parklands (Ouahigouya) to mono-woody species parklands (Bouroum-Bouroum). This diversity in agroforestry parkland profiles can be explained by farmers' considerations for woody species and services expected from these species. For instance, Vitellaria paradoxa and Parkia biglobosa agroforestry parklands have high sociocultural and local economic values, as farmers use shea (Vitellaria paradoxa) in English) butter for consumption, selling and some local rituals. This corroborates the vision of Gijsbers et al. (1994) who stated that the diversity of woody species in AFPs depend rather on sociological factors, such as farmers attitude towards trees, agricultural practices, and the importance and management of livestock.

In the Sahel strict agroforestry parklands, it was identified some woody species with apparently no significant economic value. This could constitute some adaption strategies developed by farmers in this zone to cope with the effect of drought and water scarcity which compromise sometime crop production. Moreover, the investigation revealed that the main reason of mixing crop and trees was to diversify the sources of production to secure food production particularly in Ouahigouya zone. In areas of Burkina Faso where natural resources are poor in term of provision of some services such as wood and non-timber forest products for smallholders' farmers, farmlands must play multiple roles beyond crop production to cover the others needs of farmers (Bationo et al., 2012). For instance, several studies have been reported that some species are multipurpose trees and are used to satisfy household basic needs such as medicine, basic food commodities, including a variety of gums, oils, proteins, fruits and drinks that contribute to soften malnutrition (Boffa et al., 2000). For Bationo (2007) and Yelemou et al. (2013) some agroforestry woody species such as Faidherbia albida, Piliostigma reticulatum Piliostigma thonningii have been recognized for their contribution to maintain soil moisture, especially during the 
droughts, improve soil fertility, and improve crop productivity.

Among the six-potential parklands species identified in the Sahel Strict zone, Azadirachta indica for instance is essentially used to supply firewood. The widespread of Azadirachta indica parklands in Ouahigouya can be explained by the exemption of this exotic species by national regulation on tree cutting banning. Similar results were reported by previous work in which it was argued and reported that exotic trees species which are exempted by national low on tree cutting banning are easily adopted by farmers in Western Center of Burkina Faso in their farms in order to deal with the lack of firewood's and wood needed to build their houses (Bationo et al., 2012).

The absence of regeneration and the instability of agroforestry parklands could influence the continuous function of parklands to sequester dioxide carbon $\left(\mathrm{CO}_{2}\right)$ given that the country planned to promote agroforestry parkland to meet the objectives of its INDC (MEEVCC, 2015). However, the multi-woody species parklands observed in Ouahigouya and Sapouy is a good sign for the country in term of carbon sink potential and opportunity for its INDC implementation. Because, several authors argued and reported that woody species variety on a given land use influence its capability to stock carbon (Oostra et al., 2006; Schulp et al., 2008; Bunker et al., 2012) as the capacity of each individual tree to sequester $\mathrm{CO}_{2}$ is intimately dependant to its species (Chave et al., 2014; Chabi et al., 2016, Ali et al., 2017).

\section{Conclusion}

The study revealed that agroforestry parklands are rich in woody species 42 in Bouroum-Bouroum, 34 in Ouahigouya and 31 in Sapouy with higher richness in Ouahigouya and their density per hectare follow more or less the same trend as the number of species. Among the woody species found 12 are common to the three climatic zones. Trees density was $35 \pm 7 /$ ha in Ouahigouya, $30 \pm$ 7 trees/ha in Sapouy and 37 \pm trees /ha in Bouroum-Bourom. However, DBH class's distribution revealed that agroforestry parklands in Bouroum-Bouroum and Ouahigouya were stable while those in Sapouy community were unstable. Parkland typology analysis revealed a mono-woody species parkland of Vitellaria paradoxa in Bouroum-Bouroum, three (03) dominant multi-woody species (Vitellaria paradoxa, Parkia biglobosa and Bombax constatum) in Sapouy parklands and six dominant multiwoody species (Adansonia digitata, Azadirachta indica ,Balanites aegyptiaca , Faidherbia albida, Lannea microcarpa and Sclerocarya birrea) in Ouahigouya parklands. Although significant differences were not found in terms of total number of species and trees density, it may be argued that the agroforestry parklands profiles are impacted by climatic conditions and particularly average total rainfall in Burkina Faso. Multiwoody species agroforestry parklands observed in the Sahel strict zone appeared to be the more resilient to climate variability and change and could therefore be advised as a strategy to cope with the adverse effects of climate variability on rural livelihood. It is also obvious that the number of species in AFPs would influence their capacities in terms of carbon sequestration. There is therefore a need to deepen investigations to unveil a likely correlation between AFPs number of species and their carbon stocks.

\section{COMPETING INTERESTS}

Authors have declared that no competing interests exist.

\section{AUTHORS' CONTRIBUTIONS}

This work was carried out in collaboration between all authors. TN designed the study, performed the statistical analysis, and wrote the first draft of the manuscript. ON and AAA guided the design of the study and supervised data collection and analyses of the study.

\section{REFERENCES}

Agali AB. 2009. Diversité, structure et perceptions locales des espèces ligneuses fourragères dans le terroir de Torodi, 
Ouest Niger. Mémoire de DEA en Biologie et Ecologie végétales. Université de Ouagadougou, Burkina Faso, p. 48.

Ali A, Mattsson E. 2017. Individual tree size inequality enhances aboveground biomass in homegarden agroforestry systems in the dry zone of Sri Lanka. Science of Environment, 575: 6-11. https://doi.org/10.1016/j.scitotenv.2016.1 0.022

Angoni H, Ongolo RS, Baptiste J, Melingui N, Laure M, Mpeck NGO. 2018. Composition floristique, structure et menaces de la végétation de la ligne côtière de la Réserve de Faune de Douala-Edéa Floristic composition, structure and threats of the vegetation of the coastal line of the Douala-Edéa Wildlife Reserve. Int. J. Biol. Chem. Sci., 12(2): 915-926. DOI: https://dx.doi.org/10.4314/ijbcs.v12i2.23

Boffa JM. 2000. Les parcs agroforestiers en Afrique de l'Ouest: clés de la conservation et d'une gestion durable. Unasylva, 51: 11-19.

Bationo BA, Kalinganire A, Bayala J. 2012. Potentialités des ligneux dans la pratique de l'agriculture de conservation dans les zones arides et semiarides de l'Afrique de l'Ouest : Aperçu de quelques systèmes candidats. ICRAF Technical Manual no. 17 World Agroforestry Centre: Nairobi.

Bayala J, Sanou J, Teklehaimanot Z, Kalinganire A. 2014. Parklands for buffering climate risk and sustaining agricultural production in the Sahel of West Africa, ScienceDirect, 6: 28-34. https://doi.org/10.1016/j.cosust.2013.10. 004

Bunasols. 1992. Etude pédologique des provinces du Yatenga et du Passoré. Ouagadougou, p46 + annexes.

Bunker DE, Declerck F, Bradford JC, Colwell RK, Perfecto I, Naeem S. 2012. Species Loss and Aboveground Carbon Storage in a Tropical Forest. Science, 310: 10291031.

DOI: https://doi.org/10.1126/science.1117682

Chabi A, Lautenbach S, Oladokoun V, Orekan A, Baffour NK. 2016. Allometric models and aboveground biomass stocks of a West African Sudan Savannah watershed in Benin. Carbon Balance and Management, $\quad$ 11(1): 16. https://doi.org/10.1186/s13021-0160058-5

Chave J, Ejou-Mechain M, Burquez A, Chidumayo E, Colgan MS, Delitti WBC, Duque A, Eid T, Fearnside PM, Goodman RC, Henry M, Martinez Yrizar A, Mugasha WA, Mullerlandau H. C, Mencuccini M, Nelson BW, Ngomanda A, Nogueira EM, OrtizMalavassi E, Pelissier R, Ploton P, Ryan CM, Saldarriaga JG, Vieilledent G. 2014. Improved allometric models to estimate the aboveground biomass of tropical trees. Global Change Biology, 20(10): 3177-3190. DOI: $10.1111 / \mathrm{gcb}$. 12629

Gijsbers HJM, Kessler JJ. 1994. Dynamics and natural regeneration of woody species in farmed parklands in the Sahel region (Province of Passore, Burkina Faso). Forest Ecology and Management, 64: $1-12$.

Guinko S. 1984. Végétation de la HauteVolta, Thèse d'État, Sciences naturelles, université de Bordeaux, p 318.

IFN2. 2012. Base Nationale de Donnees Topographiques, IFN2, p60.

MECV. 2009: Arrete conjoint $n^{\circ}$ (2009) - 073 IMECV/MAHRH, portant reglementation des detrichements agricoles au Burkina Faso, MECV, p3

MEEVCC. 2015. Intended Nationaly Determined Contribution (INDC) Burkina Faso, p 51.

MEF. 2010. Contribution des ONG et associations de developpement a la lutte contre la pauvrete au Burkina Faso. p 121.

Mertz O, Mbow C, Reenberg A, Diouf A. 2009. Farmer's perceptions of climate change and agricultural strategies in rural Sahel. J. Environ Manage, 4: 804-816. doi:10.1007/s00267-008-9197-0.

Miguel A. Altieri FR. Funes-MonzotePaulo P. 2011. Agroecologically efficient agricultural systems for smallholder farmers: contributions to food sovereignty Agron. Sustain. Dev., 32: 1- 
13 DOI 10.1007/s13593-011-0065-6.

Nair PKR, Kumar BM, Nair VD. 2009. Agroforestry as a strategy for carbon sequestration. Journal of Plant Nutrition and Soil Science, 172(1): 10-23. https://doi.org/10.1002/jpln.200800030.

Neya T, Daboue E, Neya O, Ouedraogo I, Sena KY. 2017. Tolerance à la dessiccation des semences de Parinari curatellifolia planch. ex benth, Vitex doniana sweet et Zanthoxylum zanthoxyloides (lam) watermann au Burkina Faso. Int. J. Biol. Chem. Sci., 11(6): 2730-2744. DOI: https://dx.doi.org/10.4314/ijbcs.v11i6.14

Nhemachena C. 2009. Agriculture and future climate dynamics in Africa: impacts and adaptation options. Ph.D. Thesis. Department of Agricultural Economics, Extension, and Rural Development, University of Pretoria, South Africa, p 124

Oostra S, Majdi H, Olsson M, 2006. Impact of tree species on soil carbon stocks and soil acidity in southern Sweden. Scandinavian Journal of Forest Research, 21: 364-371.

Ouedraogo I, Savadogo P, Tigabu M, Cole R, Oden PC, Ouadba JM. 2009. Is rural migration a threat to environmental sustainability in Southern Burkina Faso? Land Degradation and Development, 20: 217-230.

Pare S, Soderberg U, Sandewall M, Ouadba JM. 2008. Land use analysis from spatial and field data capture in southern Burkina Faso,West Africa. Agriculture Ecosystems \& Environment 127: 277285.

Pouliotte J, Smit B, Westerhoff L. 2009. Adaptation and development: livelihoods and climate change in Subarnabad, Bangladesh. Clim Change Dev, 1: 3146.

Schulp CJE, Nabuurs G, Verburg PH, Waal R. WD. 2008. Forest Ecology and Management Effect of tree species on carbon stocks in forest floor and mineral soil and implicationsfor soil carbon inventories, 256: 482-490. https://doi.org/10.1016/j.foreco.2008.05. 007

Teklehaimanot JSJB. 2012. Effect of shading by baobab (Adansonia digitata) and ne (Parkia biglobosa) on yields of millet (Pennisetum glaucum) and taro (Colocasia esculenta) in parkland systems in Burkina Faso, West Africa. Agroforest Syst, $\quad \mathbf{8 5}(3)$ : 431-441. https://doi.org/10.1007/s10457-0119405-4

Tiébré M, Ouattara D, Tra B, Vroh A, Gnagbo A, Edouard K. 2016. Diversité floristique et disponibilité des plantes utilitaires en zone soudanienne de la Côte d'Ivoire. Journal of Applied Biosciences, 102(1): 9699-9707. http://dx.doi.org/10.4314/jab.v102i1.4

Thiombiano DNE, Lamien N, Dibong SD, Boussim IJ. 2013. Etat des peuplements des espèces ligneuses de soudure des communes rurales de Pobé-Mengao et de Nobéré ( Burkina Faso ). Journal of Animal \& Plant Sciences, 9(1): 11041116.

Vliet NVan, Reenberg A, Rasmussen LV. 2013. Scientific documentation of crop land changes in the Sahel: A half empty box of knowledge to support policy? Journal of Arid Environments, 95: 1-13. https://doi.org/10.1016/j.jaridenv.2013.0 3.010

Yameogo G, Yélémou B Traoré D. 2005. «Pratique et perception paysannes dans la création de parc agroforestier dans le terroir de Vipalogo (Burkina Faso)», $B A S E$ 9: 241-248 URL : http://popups.ulg.ac.be/17804507/index.php?id=1404.

Yelemou B, Sidzabda DD, Dasmane B, Georges Y, Salawu A. 2013. Soil carbon and nitrogen dynamics linked to Piliostigma species in ferugino-tropical soils in the Sudano-Sahelian zone of Burkina Faso, West Africa. Journal of Forestry Research, 24(1): 99. 